Journal of Applied Finance \& Banking, Vol. 11, No. 5, 2021, 1-27

ISSN: 1792-6580 (print version), 1792-6599(online)

https://doi.org/10.47260/jafb/1151

Scientific Press International Limited

\title{
Governance, Financial Development and Economic Growth in the WAEMU area: Evidence from panel ARDL analysis
}

\author{
DRAMA Bedi Guy Hervé
}

\begin{abstract}
The objective of this work is to estimate the long-term effects of governance quality on financial development and the real sector growth in WAEMU zone covering the period of 1996 to 2018. To this end, we utilize the Pooled Mean Group (PMG) method to estimate a nonlinear panel through the ADRL model proposed by Pesaran et al., (1999) and Pesaran and Smith, (1995). The results show that the quality of certain governance factors determines the financial system and its capacity to accelerate growth in long run. The study demonstrates that the marginal effect of financial development on growth is about 0.69 point for a given threshold of governance quality. This outcome means that financial development affects positively growth and the governance level sustains that positive effect despite the poor quality of governance comprises between -1 and 1 . Therefore, an improvement of governance quality will provide a favourable environment for financial development and consequently for economic growth. The study finally calls policy maker to more strengthen democracy and rule of law, this could offer more guarantees to banks for granting long-term credits.
\end{abstract}

JEL classification numbers: C23, E44, G21.

Keywords: Growth, Financial development, PMG, MG, WAEMU.

${ }^{1}$ Department of Economics, Peleforo Gon Korhogo University, Republic of Cote d'Ivoire.

Article Info: Received: March 14, 2021. Revised: May. 22, 2021.

Published online: May 31, 2021. 


\section{Introduction}

Since the pioneering work of Schumpeter (1912), financial development has become a subject of intense analysis for economists. In particular, the link between financial deepening and growth has given rise to a great deal of theoretical and empirical work. Until the 1990s, most studies showed that financial development has a positive long-term effect on economic activity and that inadequate development of the financial system is an obstacle to growth and that its reform should be considered a priority. In this context, restrictions on financial activity could only hinder the development of the financial sector and reduce its impact on the economy. This thesis will be taken up and defended by the theorists of financial repression (McKinnon, 1973; Shaw, 1973) who will advocate therapies in favour of freedom choice for banks in pricing of their intermediation services. The aim is to remove the distortions associated with the administration of interest rates in order to allow banks to be more efficient in mobilizing savings and financing the economy. A rigid financial system where the state controls the banking system is inefficient because the government disrupts relative prices and the allocation of resources by maintaining very low interest rates and very high and unproductive reserve requirements. Only free market forces can make the financial sector efficient, and the policy of financial liberalisation is confused with financial development policy.

Based on theses of neo-liberal theories, many developing countries will adopt reforms to liberalize their financial systems under the auspices of the $<<$ Consensus of Washington $\gg$ supported by the Bretton Woods Institutions. The countries of the West African Economic and Monetary Union (WAEMU) have not escaped this situation of financial liberalisation. The economic and banking crises of the 1980s forced these countries to embark, as early as 1989, on the liberalisation of their financial systems. The reforms were intended to revive financial activity in the Union in order to support economic growth and poverty reduction strategies. However, the results of these policies have been mixed and often disappointing particularly for sub-Saharan African countries, after more than a decade of economic and financial reforms, these policies have not led to financial deepening or an increase in savings, investment and growth rates (Mahar and Williamson, 1998; Bandiera et al., 2000; Diery and Yasim, 1993; Chouchane-Verdier, 2004; Reinhart and Tokatlidis, 2003).

The WAEMU countries are no exception to this observation of failure. With the exception of few countries (Cote d'Ivoire and Togo), there has been a contraction of credit to economy and stagnation of savings rates. Nevertheless, the reforms have brought an improvement in macroeconomic, financial environment and have raised various issues related to difficulties in implementing the various measures depending on initial conditions, their sequence and speed. Questions have therefore arisen about the capacity of financial reforms to promote savings and economic growth. Why do some African countries (such as those of the WAEMU) fail to ensure their financial and economic development, while others (East Asian 
countries, for example) do? Why is financial development successful in promoting growth in some countries and unsuccessful in others? Several arguments have been put forward to justify the mixed results of the reforms. Some argue that financial repression theory does not take into account the segmentation of financial systems in developing economies and the predominance of the informal financial sector (Van Wijnbergen, 1983; Eboue, 1990; Atindehou et al. 2005). For others, there are asymmetries information and transaction costs that limit the interest rate play and prevent reforms from being effective (Stiglitz and Weiss, 1981; Cho, 1986). There are particularly strong arguments for the view that the performance of the financial system cannot be the result of financial liberalism alone, but of the interaction of a more complex set of data that are not solely the result of changes in financial regulations.

In particular, policies and institutional arrangements play a key role in the relationship between finance and growth; the quality of institutions can even be seen as the primary determinant of financial and economic development (Acemoglu et al. 2004; Rodrik and Subramanian, 2003). Institutional issues are undeniably relevant in as much as the dominant development paradigm until the early 1990s failed to explain the failure of development policies drawn from its theoretical corpus. By exploring this new line of research, it becomes possible to explain almost entirely the failures of developing countries. An adequate institutional environment would contribute to financial development and increase its effect on growth. On the contrary, a deficient institutional system distorts the functioning of markets and penalizes economic growth. The basic assumption that emerges from this reasoning is that financial reforms can only promote financial sector development when the economic system is anchored in a credible and adequate legal institutional structure (Arestis et al. 2002). Based on this hypothesis, this study analyses the link between the quality of governance, financial development, and economic growth in the WAEMU space. It proposes to provide answers to the following research questions. How and to what extent does the quality of governance influence the level of financial development and its contribution to economic growth in WAEMU countries in long run? Does the quality of governance in these countries constitute an obstacle to the development of financial sector and real growth? What aspects of governance seem to be the most important to reform within the framework of common monetary policy? The objective of this study is to empirically examine the relationship between finance, governance and economic growth in WAEMU countries. Emphasis will be placed on different aspects of governance such as the rule of law, political stability, corruption and democracy. The study will examine the contribution of each of these governance dimensions to finance and real growth in order to provide elements that can help policy makers to initiate reforms to sustain endogenous growth in the Union.

The remainder of the study is organized as follows. Section 2 presents a review of the academic literature on the relationship between financial development, governance and economic growth. Then section 3 presents the methodology and variables used to conduct the study. The estimation results are discussed in Section 
4. The section 5 study concludes by highlighting the main findings and policy recommendations.

\section{Literature review}

This section reviews the theoretical and empirical literature on the link between financial development, institutions, and economic growth. The first part examines the link between finance and economic growth. We will see that this relationship still remains ambiguous. We explain this ambiguity by methodological problems and insist in particular on the non-linear nature of the relationship. In a second part, we discuss how institutions can condition the meaning of this relationship.

Firstly, financial development is the process by which a financial system gains depth, accessibility, efficiency and diversity. Since the work of Schumpeter (Schumpeter, 1912) and Gurley and Shaw (1955), the analysis of the role of the financial system in the growth process has been enriched with the development of theoretical models of endogenous growth that incorporate the financial sphere. The development of financial sphere is capable of stimulating growth in the real sector through three main mechanisms:

i. the adoption of technological innovations that increase factor productivity,

ii. an increase in the economy's savings rate and

iii. the efficient allocation of resources.

However, the fulfilment of these functions may be hampered by the existence of information asymmetries and transaction costs that would deter financial intermediaries from entering into risky contractual relationships. Indeed, Greenwald et al (1994) argue that problems of information asymmetry, with their corollaries of anti-selection and moral hazard, which are specifically endemic to financial markets, can distort the free functioning of markets and thus call into question their efficiency. This suggests, therefore, that a developed financial sector does not always promote the efficient allocation of real resources in the economy. The literature on financial crises, and more recently the subprime crisis, illustrates the potential destabilisation risk associated with excessive credit growth in a context of endemic uncertainty. The work of Berthelemy and Varoudakis (1995) shows that by admitting the existence of technological externality of the financial sector on the real sector, multiple equilibrium situations can be observed. Below a threshold of financial sector development, the economy is stuck at a low equilibrium which constitutes a poverty trap. The search for the positive effects of financial development on growth must start with the convergence clubs defining countries with similar economic and financial characteristics. The existence of threshold effects associated with multiple equilibria helps to explain why in some cases financial development appears neutral with respect to the real sphere, while in others it exerts a positive influence. These various contradictory theories have given rise to vast empirical literature. Some studies have sought to test the empirical validity 
of the theories by specifying growth equations involving indicators of financial development. Others have sought instead to test the direction of causality between finance and economic growth. In both cases, the results are ambiguous and controversial. See for example, (King and Levine, 1993, Odedokun, 1996; Levine and Zervos, 1998; Calderon and Liu, 2003; Burcu et al., 2009), but also questioned by many others (De Gregorio and Guidotti, 1995; Ram, 1999; Zhang, 2003). Ambiguous results have been observed when the countries studied are law income countries WAEMU region, Joseph et al (1998).

There are several reasons for these ambiguities. First, one of the criticisms against most of previous work is the problem of endogeneity of financial indicators. Indeed, according to Robinson (1952), demand for financial services grows with the level of development of the real sector. Thus, the development of finance becomes, through demand, a consequence of economic growth. To correct this problem, Levine et al. (2000) proposed the use of the generalized method of moments (GMM) for dynamic panel and the instrumental variable method for cross-sectional data. However, the problematic choice of instrumental variables in an econometric model can significantly affect the estimators; the remedy can often be worse than harm. Second, another possibility is that economic, social, financial and institutional differences between countries mean that the relationship between finance and growth is not always linear, but conditional on the different circumstances of economies, see (Berthelemy and Varoudakis, 1998; Rioja and Valev, 2004; Deidda and Fattouh, 2002; Rousseau and Wachtel, 2002) among other.

Secondly concerning the role of institutions in finance and economic growth, a vast literature has accumulated in recent years to show that macroeconomic stability and financial liberalization are not sufficient to deepen financial sectors and drive growth, and that these policies should accompany other institutional reforms. Using gross domestic product per capita as a measure of economic development, many economists argue that global differences could be explained by the quality of institutions or governance. Growth would be strong when governance is good and weak when they are deficient. By improving certain laws and their enforcement, it is possible to stimulate economic growth, particularly for African countries. This renewed interest in institutions follows on the heels of the work of the new institutional economics, including that of North, (1990). According to the definition proposed by North (1990), institutions are the set of rules and norms of society or more formal way, the constraints established by men who frame and regulate the behaviours. This includes both formal institutions (such as rules, laws, and constitutions) and informal institutions (such as unwritten norms of social behaviour, conventions, and self-imposed codes of conduct). Based on this definition, Acemoglu et al. (2004) distinguish between economic and political institutions. Economic institutions structure the rules of economic game and concern for example, property rights, contract enforcement and market transparency. Political institutions include for example, the rule of law, political stability and absence of violence, control corruption, democracy, government effectiveness and regulatory quality, Kaufmann et al. (2010). It is the responsibility 
of political institutions to ensure that the rules of law are respected to ensure that the spheres of production and trade function properly. Conversely, economies without an efficient legal system suffer from weak incentives for loan activities and the establishment of financial transactions. They also create a market for nonproductive activities such as rent-seeking or corruption, which generate high transaction costs and misallocation of resources. Improving the institutional framework is expected to reduce these market imperfections. Also, to benefit from financial openness and liberalization, financial systems need to be strengthened by sufficiently developed and efficient legal and institutional infrastructure. These arguments are supported by intellectual leaders like Knack and Keefer (1995), Levine and Renelt, (1992); Wurgle (2000) and De Gregorio and Guidotti, (1995). In sum, this literature review suggests that the ambiguity of the link between financial development and growth can be removed by incorporating the level of institutional development into the analysis. We are therefore tempted to conclude that the low levels of financial development and economic performance of subSaharan African countries are consequences of poor quality of their institutions or governance. It remains to be seen whether this result can be valid at the level of WAEMU countries.

\section{Model specification, variables definition, data sources and methodology applied}

\subsection{Econometric model specification, variables definition and data sources}

The problem we address here leads us to retain as basic theoretical model, that of Solow (1956), which considers investment rates, population growth and technical progress as exogenous. The two inputs, capital and labour, are remunerated at their marginal productivities. To relate the effects of financial development and institutions quality on economic growth, we follow the approach of Gregory et al. (1992), Demetriades and Law (2004). We assume a Cobb-Douglas production function that's output at time $(t)$ is given by:

$$
Y_{i t}=F\left(A_{i t}, L_{i t}, K_{i t}\right)=A_{i t} K_{i t}^{\alpha} L_{i t}^{\beta}
$$

with $0<\alpha<1$ and $0<\beta<1$

Whereas $Y_{i t}$ is real gross domestic production level in the country $i$ at time $t$, $K_{i t}$ represents the capital, $L_{i t}$ the labour level and $A_{i t}$ is depicted by the global productivity factors which reflects the technology and the economic efficiency. $L_{i t}$ and $A_{i t}$ are assumed to grow at exogenous rates $(n)$ and $(g)$ respectively.

$L_{i t}=L_{0} e^{n i t}$ and $A_{i t}=A_{0} e^{g i t}$ 
An improvement in productivity can be the result of developed financial system and institutional framework or good quality of governance (Benhabib and Spiegel 2000; Pagano, 1993; North, 1990; Nelson and Sampat, 2001).

Thus we suppose that:

$$
A_{i t}=G(D f, G o v)=A_{0} e^{\theta_{z i t}}
$$

With Gov represents the governance or institution quality and $D f$ financial development indicator. To capture the fact that institutions condition the effect of financial development on economic activity, we introduce an interaction variable between these two variables. Thus, we pose that:

$$
z_{i t}=\left(D f_{i t}, D f_{i t} * G o v_{i t}\right)
$$

Where $(D f * G o v)$ highlights the governance interaction effect of financial development on economic activity. By combining the equations (1) and (3) and taking the logarithms, we get the following equation (5) written as follow:

$$
Y_{i t}=\alpha_{0}+\alpha k_{i t}+\beta l_{i t}+\theta z_{i t}+\mu_{i t}
$$

Whereas $y, l$ and $k$ represent the $\log$ of $Y, K$ and $L$, respectively and $\mu_{i t}$ the error term. We assume that the accumulation of physical capital follows a process of the form:

$$
k_{i t}=(1-\delta) k_{i t-1}+i_{i t} \text { with } k_{i t}=(1-\gamma L)^{-1} i_{i t}
$$

Whereas $\delta$ is the depreciation rate of capital and $i_{t}$ the investment level ${ }^{2}$. By substituting (6) in (5) and assuming that the labour force grows at a constant rate, we obtain the evolution of real growth per capita as follow:

$$
Y_{i t}=\alpha_{0}(1-\gamma)+\gamma Y_{i t-1}+\alpha i_{i t}+\varphi t+\beta_{2} D f_{i t}-\gamma \beta_{2} D f_{i t-1}+\gamma \beta_{3} D f_{i t-1} * G o v_{i t-1}+\mu_{i t}^{\prime}
$$

\footnotetext{
2 The financial sector acts as intermediary between savings and investment. As in Pagano (1993), it is assumed that only a portion of household savings $S$ can be used for productive investment $i$. We assume that the fraction of savings lost in the intermediation process is a deadweight loss for households, but it could be reintroduced into their budget constraint as a lump-sum transfer, without any change in the model. In fact, this model assumes that financial intermediation does not require capital (see Berthelémy and Varoudakis, 1994 for a similar assumption).
} 
Given the importance of financial development for growth, let us now turn to the study of its determinants. According to the literature, we specify the model in the following form:

$$
D f_{i t}=\phi_{0 i}+\phi_{1} D f_{i t-1}+\phi_{2} G o v_{i t-1}+\phi_{3} Y_{i t}+\phi_{4} I n f_{i t}+O p_{i t}+\gamma^{\prime} X_{i t-1}+\tilde{\mu}_{i t}
$$

Whereas $\operatorname{Inf} f_{i t}$ is Inflation in country $i$ in year $t$ defines as consumer price index, $O p_{i t}$ is the openness rate measures by the ratio of total value of trade (export+import) to GDP in country $i$ in year $t$ and we suppose that:

$$
X_{i t-1}=\left(G o v_{i t-1}, Y_{i t-1}, O p_{i t-1}\right)
$$

Because WAEMU countries follow a common monetary policy, nominal interest rates are the same and therefore real interest rates correlate with the inflation rate. The inflation rate is often considered to be an indicator of financial repression, in particular because of the seigniorage (McKinnon, 1973; Giovannini and De Melo, 1993). Inflation lowers the real interest rate, which has negative effects on the credit volume, the level of investment and the economic activity (Huybens and Smith, 1999; Boyd et al. 2001). Also the introduction of the openness rate follows the work of Rajan and Zingales (2003) who show that a trade opening, at the same time as a financial opening, are likely to positively influence the development of the financial sphere. The objective of our work is to estimate the long-term effects of governance or institutions quality on financial development and growth of the real sector in WAEMU zone. Following the dynamic model developed by King and Levine (1993), Gregory et al (1992), Moez Ouni, (2011), Kuipou T. Christophe et al., (2015) and from the dynamic models depicted in equations (7) and (8), we can derive the long-term relationships in the written forms:

$$
\begin{gathered}
Y_{i t}=\alpha_{0 i}+\beta_{0} Y_{i t-1}+\beta_{1} O p_{i t}+\beta_{2} \operatorname{Inf}_{i t}+\beta_{3} D f_{i t}+\beta_{4} \operatorname{Gov}_{i t}+\beta_{5}\left(D f_{i t} * G o v_{i t}\right)+\Omega_{i t}+\mu_{1 i t} \\
D f_{i t}=\delta_{0}+\delta_{1} \operatorname{Inf}_{i t}+\delta_{2} O p_{i t}+\delta_{3} G o v_{i t}+\delta_{4} Y_{i t}+\Omega_{i t}+\mu_{2 i t}
\end{gathered}
$$

After the specification of our main equation, the variables definitions are presented in table 1 bellow. 
Table 1: Variable's definitions

\begin{tabular}{|c|c|c|}
\hline Variables & Definitions and measurement & Sources \\
\hline \multicolumn{3}{|c|}{ Dependent variables } \\
\hline$Y_{i t}$ & $\begin{array}{l}\text { The real GDP per capita in country } i \text { in year } t \text { that measures } \\
\text { the average income of economic agents. }\end{array}$ & WDI(1996-2018) \\
\hline \multicolumn{3}{|c|}{ Independent variables } \\
\hline$O p_{i t}$ & $\begin{array}{l}\text { The openess rate measures by the ratio of total value of trade } \\
\text { (export+import) to GDP in country } i \text { in year } t\end{array}$ & WDI(1996-2018) \\
\hline $\operatorname{Inf}_{i t}$ & $\begin{array}{l}\text { Inflation in country } i \text { in year } t \text { defines as consumer price } \\
\text { index. }\end{array}$ & WDI(1996-2018) \\
\hline \multicolumn{3}{|c|}{$\begin{array}{l}\text { Financial development indicators } \\
\end{array}$} \\
\hline $\begin{array}{l}C P S_{i t} \\
D S C B_{i t} \\
M_{i t} \\
D f_{i t}\end{array}$ & $\begin{array}{l}\text { Credit granted to the private sector as percentage of GDP. } \\
\text { Domestic credit granted by the banking sector as percentage of } \\
\text { GDP. } \\
\text { Money supply ratio as percentage of GDP } \\
D f_{i t}=\left(C P S_{i t}, D S C B_{i t}, M_{i t}\right) \text { We generated financial } \\
\text { development composite indicator by combining these three } \\
\text { variables mentioned above. }\end{array}$ & $\begin{array}{l}\text { WDI(1996-2018) } \\
\text { WDI(1996-2018) }\end{array}$ \\
\hline \multicolumn{3}{|c|}{ Institutional quality } \\
\hline$S p_{i t}$ & Political stability and absence of violence & WGI(1996-2018) \\
\hline Corr $_{i t}$ & Control of corruption & WGI(1996-2018) \\
\hline $\operatorname{Rol}_{i t}$ & Rule of low & \\
\hline $\operatorname{Dem}_{i t}$ & Democracy & WGI(1996-2018) \\
\hline$G o v_{i t}$ & $\begin{array}{l}\operatorname{Gov}_{i t}=\left(\operatorname{Sp}_{i t} \operatorname{Corr}_{i t}, \operatorname{Rol}_{i t}, \operatorname{Dem}_{i t}\right) \text { We also generated } \\
\text { governance composite indicator by combining these four } \\
\text { variables mentioned above. } \\
\text { Is dummy variable capturing the changes that have occurred } \\
\text { following the currency devaluation and the creation of } \\
\text { WAEMU in } 1994 \text {. }\end{array}$ & \\
\hline
\end{tabular}

Source: Constructed by Author

Our variables are selected following a review of the literature. The data we use in this study are annual and come from the World Bank's World Development Indicator (2019) database for the period 1996-2018. They concern seven (7) WAEMU countries, namely, Benin, Burkina Faso, Côte d'Ivoire, Mali, Niger, Senegal, and Togo, given the unavailability and inadequacy of data for Guinea Bissau. The governance indicator variables are extracted from the database, Worldwide Governance Indicators (WGI, 2019). Of the six governance development indicators in the database, we have opted for four indicators for the study. Institutional development measures are rated between -2.5 and 2.5 (ranging from poor to good quality). Higher values reflect better quality of governance. The 
governance $^{3}$ variables used in this work is selected according their availability. Using all of these four indicators at the same time in the analysis can cause problems with multicollinearity because these variables could be highly correlated. There is also the risk of overidentification due to the high number of coefficients to be estimated. On the other hand, using each of these variables could lead to variable omission bias. One solution to arbitrate between these problems is to combine the variables into single indicator with specific weights. Obviously, such an approach comes up against the question of choice of weightings to be given to each variable. In order to avoid any subjectivity in the definition of these weights, we resort to a principal component analysis (PCA) ${ }^{4}$.

\subsection{Methodology applied}

The study introduces two major methodological innovations. First, while most studies use a linear type of modelling, the present study instead adopts a non-linear approach to the relationship between finance, governance and growth through interaction effects between finance and governance quality and at the same time we construct composite indicators of governance and financial development. In this way, we explicitly take into account the fact that the effect of financial development on economic activity may be conditioned by the quality of governance. Second, the study uses an estimation technique that is relatively efficient compared to standard panel data methods. Specifically, we use the Pool Mean Group (PMG) and Mean Group (MG) methods proposed by Pesaran et al (1999) and Pesaran and Smith (1995) respectively. The advantage of these estimation methods over conventional methods such as (two steps generalized method of moment (GMM) Arellano and Bond (1991), system generalized method of moment Arellano and Bover (1995), pooled estimations of seemingly unrelated regressions (SUR), fixed effect estimations...etc.) is that they introduce heterogeneity into some coefficients to be estimated. Indeed, the Pooled Mean Group (PMG) and Mean Group (MG) estimation methods allow heterogeneity in the dynamic's adjustment of the variables towards the long-term relationship proposed by Pesaran and Smith (1995) and Pesaran et al. $(1999,2001)$. The advantage of the first estimator is that it considers the heterogeneity of the long-term coefficients by taking their average while the second considers the combination of pooling and the average of coefficients. According to Pesaran et al. (1999), the dynamic model of equation (8) can be seen as an autoregressive dynamic lag model (ADRL) of the form:

\footnotetext{
3 The corruption indicator measures the extent of corruption and manner in which public power is exercised for private purposes. Democratic accountability measures how the government responds to its people and its ability to build a democratic society. The indicator rule of law reflects the strength and impartiality of the judicial system and the degree of respect for the law by citizens. Finally, the political stability measures the ability of the government to carry out the programmes it has planned and to sustain itself without any violence.

4. The normalisation method should take into account the data properties, as well as the objectives of the composite indicator. Robustness tests might be needed to assess their impact on the outcomes, see Handbook on Constructing Composite Indicators Methodology and user Guide P.30 (OECD 2008)
} 


$$
y_{i t}=\sum_{j=1}^{p} \lambda_{i j} y_{i t-j}+\sum_{j=0}^{q} \beta_{i j}^{\prime} x_{i t-j}+\mu_{i}+\varepsilon_{i t}
$$

The number of individuals $i=1,2, \ldots, N$; the number of period $t=1,2 \ldots, T ; x_{i t} \quad$ is the vector of explanatory variables and $u_{i}$ the fixed effect (country). If the variables are cointegrated then the error term $\varepsilon_{i t}$ is a stationary process. In this case the model can be re-specified in the form of an error-correction model where the short-term dynamics are influenced by the long-term relationship:

$$
\Delta y_{i t}=\phi_{i}\left(y_{i t-1}-\theta_{i}^{\prime} x_{i t}\right)+\sum_{j=1}^{p-1} \lambda_{i j}^{*} \Delta y_{i t-1}+\sum_{j=0}^{q-1} \delta_{i j}^{*}+u_{i}+\varepsilon_{i t}
$$

The parameter $\theta_{i}$ is the vector of the long-term coefficients and $\Delta$ the variation operator between two successive dates. The adjustment coefficient $\phi_{i}$ and the long term coefficients $\theta_{i}$ are the parameters of interest. $\theta_{i}$ is particular importance since it contains the long-term coefficients. In addition, it is expected that $\phi_{i}<0$ under the assumption that the variables adjust in the long term. In addition, ARDL models allow variables that can be integrated of different orders, as $I(0)$ and $I(1)$, or cointegrated (Pesaran and Shin, 1999). The PMG estimator allows the short-term coefficients and the adjustment coefficient to vary across countries, but the long-term coefficients are same for all countries $\left(\theta_{i}=\theta\right)$. It has been shown that imposing the same coefficient for the recall force could lead to bias (Kiviet, 1995). The MG estimator allows for heterogeneity in both short-term parameters and long-term coefficients. Thus, the model can be estimated separately for each group, and a simple arithmetic mean of the coefficients can be calculated. This is the idea of GM estimator proposed by (Pesaran and Smith, 1995). However, the necessary condition for validity and consistency of this method is sufficiently large time dimension.

Recently Pesaran and Smith (1995) and Pesaran et al (1999) proposed the PMG estimator which combines the average technique and pooling. This intermediate estimator is an estimator constructed under the assumption of short-term coefficients heterogeneity including constants, speed of adjustment to long-term equilibrium values and variance errors to be heterogeneous country by country and homogeneity of long-term slope coefficients. The long-term coefficients are therefore a non-linear combination of short-term coefficients. Short-term adjustment is country specific due to the different impacts of certain phenomena such as: financial crises, external shocks, stabilization policies for example. As equation (14) is not linear in the parameters, the PMG estimator uses the maximum likelihood method to estimate these parameters (Pesaran et al. 1999): 
$\hat{\phi}_{P M G}=n^{-1} \cdot \sum_{i=1}^{n} \hat{\phi}_{i} ; \quad \lambda_{j P M G}^{*}=n^{-1} \sum_{i=1}^{n} \hat{\lambda}_{i j}^{*} ; \quad \delta_{J P M G}^{* \prime}=n^{-1} \sum_{i=1}^{n} \delta_{i j}^{* \prime} ; \theta_{P M G}=\hat{\theta}$

The MG estimator estimates the equation for each country in the sample and then calculates the unweighted averages of the coefficients over the entire panel written in the form bellow:

$\hat{\theta}_{M G}=n^{-1} \sum_{i=1}^{n} \tilde{\phi}_{i} ; \quad \lambda_{J M G}^{* *^{\prime}}=n^{n-1} \sum_{i=1}^{n} \lambda_{i j}^{*} ; \quad \delta_{J M G}^{*^{*}}=n^{-1} \sum_{i=1}^{n} \delta_{i j}^{*^{*}} ; \quad \hat{\theta}_{M G}=n^{n-1} \sum_{i=1}^{n} \tilde{\theta}$

Whereas $\tilde{\phi}_{i}, \lambda_{i j}^{*} \tilde{\theta}_{i}, \delta_{i j}^{*^{\prime}}$ are the OLS estimators of the coefficients for each country .If the restriction $\theta=\theta_{i}$ is relevant, the PMG estimator is convergent and more efficient than the MG estimator (Pesaran et al. 1999). According to Hsiao et al., (1999), the PMG estimator also has the advantage over the MG estimator of having good properties even when the sample size $\mathrm{N}$ is small relative to time dimension. This test is all the most important since it allows us to empirically test the hypothesis of homogeneity of the long-term coefficients, which cannot be posed a priori. The efficient estimator under the null hypothesis is preferred if the probability associated with the Chi-square statistic is greater than $5 \%$. Once the long-term coefficients have been estimated, we examine how governance variables affect the relationship between finance and real activity. From equation (8), the marginal effect of finance is calculated as follows:

$$
\frac{\partial G D P}{\partial D F}=\beta_{3}+\beta_{5} G o v
$$

This equation shows that the marginal effect of financial development on GDP depends on the quality of governance. Governance is expected to improve the marginal effect of financial development, which should be reflected in coefficient of $\beta_{5}>0$. The common approach in empirical studies test for the existence of nonlinear effect is to simply look at the sign and statistical significance of the interaction coefficient $\beta_{5}$, then we depict all possible hypotheses in the following table 2 : 
Table 2: Hypotheses of financial development marginal effect on growth

\begin{tabular}{|c|c|c|}
\hline Hypotheses & Long run effect & Overall impact \\
\hline$H_{1}$ & $\beta_{3}>0$ and $\beta_{5}>0$ & Crowding in \\
\hline$H_{2}$ & $\beta_{3}<0$ and $\beta_{5}<0$, & Crowding out \\
\hline$H_{3}>0$ and $\beta_{5}<0$ & $\begin{array}{c}\text { Temporary crowding } \\
\text { in }\end{array}$ \\
\hline$H_{4}$ & $\beta_{3}<0$ and $\beta_{5}>0$ & Creative destruction \\
\hline$H_{5}$ & If $\left(\beta_{4}>0\right)$ & $\begin{array}{c}\text { Financial development } \\
\text { accelerates real growth } \\
\text { above the threshold } \\
\text { level. }\end{array}$ \\
\hline
\end{tabular}

Note: There is always possibility for long-term elasticity to be null and then the four hypotheses are reduced to only two, crowding out and crowding in. Source: Author based on the literature.

- If $\beta_{3}>0$ and $\beta_{5}>0$, then financial development has a positive effect on economic activity, and the quality of governance favourably affects (improves) this effect.

- If $\beta_{3}<0$ and $\beta_{5}<0$, then financial development has a negative effect on economic activity, and the level of governance negatively affects this effect.

- If $\beta_{3}>0$ and $\beta_{5}<0$, financial development has a positive effect on the economy but governance variables adversely affect (reduce) this positive impact.

- If $\beta_{3}<0$ and $\beta_{5}>0$, financial development has negative effect on economy but governance variables mitigate this positive impact.

- Under the assumption $\beta_{4}>0$, we can calculate the threshold level of the governance variable above which financial development accelerates real growth. Applying the first-order conditions, we have:

$$
\frac{\partial G D P}{\partial D F}=\beta_{3}+\beta_{5} G o v \geq 0 \Rightarrow G_{o v}{ }^{*} \geq-\frac{\beta_{3}}{\beta_{5}}
$$

However, it would be wrong to assume that for any value above this threshold, the marginal effect is positive and significant. Indeed, the traditional approach basing inference on the interaction coefficient alone $\beta_{5}$ is not rigorous or even erroneous, because it ignores the covariance between the coefficients $\beta_{3}$ and $\beta_{5}$. To make correct inference, we need to calculate the standard deviation of conditional marginal effect of finance on economy see Keho (2012) for more detail. 


\section{Empirical results and interpretations}

In this section, two tests will be addressed. These tests will allow us to draw a conclusion on the use of ARDL model. These will be the stationarity and cointegration tests. The stationary tests results are presented in table 2 bellow. These results suggest that all variables in the panel have unit root. When they are all considered as first difference, they all appear stationary. Then the series are integrated of order I(1) and therefore there is cointegration relationship between the variables. This leads us to carry out the cointegration test between the different series of panel.

Table 3: Panel unit root tests

\begin{tabular}{|c|c|c|c|c|c|c|}
\hline \multirow[b]{2}{*}{ VARIABLES } & \multicolumn{2}{|c|}{ LLC } & \multicolumn{2}{|c|}{ IPS } & \multicolumn{2}{|c|}{ MW } \\
\hline & I (0) & I (1) & I (0) & I (1) & I (0) & I (1) \\
\hline$Y$ & $\begin{array}{c}3,0166 \\
(0,9987)\end{array}$ & $\begin{array}{l}-3,176^{*} \\
(0,0007)\end{array}$ & $\begin{array}{l}5,3598 \\
(1,000)\end{array}$ & $\begin{array}{c}-6,0454^{*} \\
(0,000)\end{array}$ & $\begin{array}{c}1,1326 \\
(1,000)\end{array}$ & $\begin{array}{c}64,364 * \\
(0,000)\end{array}$ \\
\hline $\operatorname{Inf}$ & $\begin{array}{c}-7,8606 * \\
(0,000)\end{array}$ & $\begin{array}{c}-11,478 * \\
(0,000)\end{array}$ & $\begin{array}{c}-6,5168 \\
(0,000)\end{array}$ & $\begin{array}{c}-12,3371 * \\
(0,000)\end{array}$ & $\begin{array}{l}64,849 \\
(0,000)\end{array}$ & $\begin{array}{c}129,870 * \\
(0,000)\end{array}$ \\
\hline$D f$ & $\begin{array}{c}2,249 \\
(0,987)\end{array}$ & $\begin{array}{c}-8,629 * \\
(0,000)\end{array}$ & $\begin{array}{c}4,628 \\
(1,000)\end{array}$ & $\begin{array}{c}-8,902 * \\
(0,000)\end{array}$ & $\begin{array}{c}0,981 \\
(1,000)\end{array}$ & $\begin{array}{c}89,643 * \\
(0,000)\end{array}$ \\
\hline Gov & $\begin{array}{c}-5,8148 \\
(0,000)\end{array}$ & $\begin{array}{c}-12,42 * \\
(0,000)\end{array}$ & $\begin{array}{c}-6,870 \\
(0,000)\end{array}$ & $\begin{array}{c}-15,45^{*} \\
(0,000)\end{array}$ & $\begin{array}{c}88,585 \\
(0,000)\end{array}$ & $\begin{array}{c}199,997 * \\
(0,000) \\
\end{array}$ \\
\hline$D f * G o v$ & $\begin{array}{c}1,556 \\
(0,940) \\
\end{array}$ & $\begin{array}{l}-9,079 * \\
(0,000)\end{array}$ & $\begin{array}{c}2,821 \\
(0,997)\end{array}$ & $\begin{array}{l}-8,579 * \\
(0,000)\end{array}$ & $\begin{array}{c}7,208 \\
(0,926) \\
\end{array}$ & $\begin{array}{c}92,568 * \\
(0,000)\end{array}$ \\
\hline$O p$ & $\begin{array}{l}0,6810 \\
(0,752)\end{array}$ & $\begin{array}{l}-8,084 * \\
(0,000)\end{array}$ & $\begin{array}{c}2,965 \\
(0,998)\end{array}$ & $\begin{array}{l}-7,319 * \\
(0,000)\end{array}$ & $\begin{array}{c}3,361 \\
(0,998)\end{array}$ & $\begin{array}{c}74,577 * \\
(0,000)\end{array}$ \\
\hline Corr & $\begin{array}{c}-0,6383 \\
(0,2616)\end{array}$ & $\begin{array}{c}-8,0528 * \\
(0,000)\end{array}$ & $\begin{array}{l}-0,4878 \\
(0,3128)\end{array}$ & $\begin{array}{c}-7,3850 * \\
(0,000)\end{array}$ & $\begin{array}{l}15,0486 \\
(0,3748)\end{array}$ & $\begin{array}{c}74,3320^{*} \\
(0,000)\end{array}$ \\
\hline$S P$ & $\begin{array}{l}-0,6605 \\
(0,2544)\end{array}$ & $\begin{array}{c}-9,1411 * \\
(0,000)\end{array}$ & $\begin{array}{c}0,2781 \\
(0,6095)\end{array}$ & $\begin{array}{c}-8,3017 * \\
(0,000)\end{array}$ & $\begin{array}{c}14,736 \\
(0,3964)\end{array}$ & $\begin{array}{c}86,9039 * \\
(0,000)\end{array}$ \\
\hline Dem & $\begin{array}{l}-1,6143 \\
(0,0532)\end{array}$ & $\begin{array}{c}-5,475^{*} \\
(0,000)\end{array}$ & $\begin{array}{l}-2,3985 \\
(0,0082)\end{array}$ & $\begin{array}{c}-5,2413 * \\
(0,000)\end{array}$ & $\begin{array}{l}30,6026 \\
(0,0063)\end{array}$ & $\begin{array}{c}56,1775^{*} \\
(0,000)\end{array}$ \\
\hline Rol & $\begin{array}{l}-1,1013 \\
(0,1354)\end{array}$ & $\begin{array}{c}-8,3191 * \\
(0,000)\end{array}$ & $\begin{array}{c}-0,4487 \\
(0,3268)\end{array}$ & $\begin{array}{c}-7,6566 * \\
(0,000) \\
\end{array}$ & $\begin{array}{r}17,5355 \\
(0,2288)\end{array}$ & $\begin{array}{c}77,240 * \\
(0,000)\end{array}$ \\
\hline$M$ & $\begin{array}{c}3,550 \\
(0,999)\end{array}$ & $\begin{array}{c}-8,838 * \\
(0,000)\end{array}$ & $\begin{array}{c}4,807 \\
(1,000) \\
\end{array}$ & $\begin{array}{c}-8,283^{*} \\
(0,000)\end{array}$ & $\begin{array}{c}2,1007 \\
(0,999)\end{array}$ & $\begin{array}{c}84,552 * \\
(0,000)\end{array}$ \\
\hline CSP & $\begin{array}{c}1,6015 \\
(0.945)\end{array}$ & $\begin{array}{c}-9,486 * \\
(0,000)\end{array}$ & $\begin{array}{c}3,984 \\
(1,000)\end{array}$ & $\begin{array}{c}-9,107^{*} \\
(0,000)\end{array}$ & $\begin{array}{c}1,337 \\
(1,000)\end{array}$ & $\begin{array}{c}92,507 * \\
(0,000)\end{array}$ \\
\hline$D C S B$ & $\begin{array}{c}1,634 \\
(0,948)\end{array}$ & $\begin{array}{l}-9,606 * \\
(0,000)\end{array}$ & $\begin{array}{c}4,006 \\
(1,000)\end{array}$ & $\begin{array}{l}-9,174 * \\
(0,000)\end{array}$ & $\begin{array}{c}1,323 \\
(1,000)\end{array}$ & $\begin{array}{l}92,91 * \\
(0,000)\end{array}$ \\
\hline
\end{tabular}

Source: Author's calculations. Notes: IPS, LLC and MW refer to tests by Im, Pesaran \& Shin (2003), Levin, Lin \& Chu (2002) and Maddala \& Wu (1999), respectively (Fisher-ADF). The values in parentheses are the results of the tests with trends and the others without trends. $*$ and $* *$ signify the rejection of the unit root hypothesis at the $5 \%$ and $10 \%$ significance level respectively. The rejection of the null hypothesis ( $p$-value $<5 \%$ ) indicates the absence of unit root. 
The results of cointegration tests between variables are reported in Tables 4a and 4b. The cointegration of variables depends on the value of the probability (Prob) associated with each statistic in the test. The results of Kao's (1999) test allow us to reject the null hypothesis of no cointegration (Table 4a). Thus, there is a long-run relationship between financial development, governance and growth at the panel level. The results of Pedroni's (1999) cointegration test confirm this long-run relationship (see table $4 \mathrm{~b}$ ). The next step is to estimate this long-term relationship.

Table 4a: Results of Kao (1999) panel cointegration tests

\begin{tabular}{|l|c|c|}
\hline ADF & T-Statistic & Prob. \\
\hline & -3.243095 & $0.0006^{*}$ \\
\hline Residual variance & 0.000161 & \\
\hline HAC variance & 0.000177 & \\
\hline
\end{tabular}

Source: Author's calculations :* and ** indicate rejection of the null hypothesis of noncointegration at the $5 \%$ and $10 \%$ threshold respectively.

Table 4b: Results of Pedroni (1999) panel cointégration tests

\begin{tabular}{|c|c|c|c|c|}
\hline Approach & & $\mathbf{I}$ & I & \\
\hline \multicolumn{5}{|c|}{ Alternative hypothesis: common AR coefs. (within-dimension) } \\
\hline & Statistic & Prob. & Statistic & Prob. \\
\hline Panel v-Statistic & 1.751935 & 0.0399 & 1.735624 & 0.0413 \\
\hline Panel rho-Statistic & 1.463460 & 0.9283 & 1.450953 & 0.9266 \\
\hline Panel PP-Statistic & $-3.063010^{*}$ & 0.0011 & -2.805110 & 0.0025 \\
\hline Panel ADF-Statistic & $-3.003794 *$ & 0.0013 & -3.022624 & 0.0013 \\
\hline \multicolumn{5}{|c|}{ Alternative hypothesis: individual AR coefs. (between-dimension) } \\
\hline & Statistic & Prob. & & \\
\hline Group rho-Statistic & 2.562718 & $\overline{0.9948}$ & & \\
\hline Group PP-Statistic & $-1.96635^{*}$ & 0.0246 & & \\
\hline Group ADF-Statistic & $-1.864700^{*}$ & 0.0311 & & \\
\hline
\end{tabular}

Source: Author's calculations. Notes: $*$ and $* *$ indicate rejection of the null hypothesis of noncointegration at the $5 \%$ and $10 \%$ threshold respectively. "I" indicates a model with deterministic no intercepts and no trend, "II", a model with intercept but no trend.

In so doing, we use the PMG and MG estimators to estimate long-run relationships within an error-correction model. The assumption of homogeneity of long-run coefficients cannot be made in this way, it must be tested empirically. The Hausman test applied to the difference between the MG and PMG estimators is used for this purpose. The probability greater than $5 \%$ leads us to accept the null hypothesis that Pooled Mean Group estimator is appropriate (efficient) against the alternative hypothesis that Mean Group estimator is appropriate. The Hausman joint tests of our equations show that the hypothesis of homogeneity of the long-term coefficients cannot be rejected, so the interpretation of the results will focus on those of PMG method in our case study. In this sub-section, we first present and interpret the 
results of long and short term relationship between financial development governance and growth and then we analyse the short and long term relationship between economic growth, governance and financial development. Tables 5 and 6 summarize our findings.

Table 5: Estimation of Financial development equation with $\log D f$ as dependent variable.

\begin{tabular}{|c|c|c|c|c|c|}
\hline $\log D f$ & & \multicolumn{2}{|c|}{ PMG } & \multicolumn{2}{c|}{ MG } \\
\hline & Variables & Coefficients & Z-stat & Coefficients & Z-stat \\
\hline & $\operatorname{logInf}$ & $1.585^{* *}$ & 2.87 & 2.229 & 1.98 \\
\hline Long Run & $\log O p$ & $0.662^{* *}$ & 3.31 & 0.214 & 0.98 \\
\hline & Gov & $0.436^{* *}$ & 2.24 & 0.516 & 0.80 \\
\hline & $\log Y$ & $54.78^{* *}$ & -3.74 & $61.03^{* *}$ & 1.98 \\
\hline & $\Delta \log$ Inf & $-1.473^{* *}$ & -3.40 & $-1.605^{* *}$ & -2.39 \\
\hline & $\Delta \log O p$ & $-0.297 * *$ & -3.02 & -0.074 & -0.55 \\
\hline Short Run & $\Delta$ Gov & -0.405 & -0.99 & -0.359 & -0.96 \\
\hline & $\Delta \log Y$ & 0.675 & 0.92 & -0.426 & -0.83 \\
\hline & Cons & $-2.571^{* *}$ & -3.91 & $-7.612^{* *}$ & -2.25 \\
\hline & $\psi$ & $-0.432^{* *}$ & -4.15 & $0.693 * *$ & -7.08 \\
\hline \multicolumn{7}{|c}{ Joint Hausman test(MG, PMG)=0.326 } \\
\hline
\end{tabular}

Source: Calculations by the author. Notes: $* * *$ and $* * *$ denote respectively the significance of the coefficients of the variables of interest at the $1 \%, 5 \%$ and $10 \%$ level. $\psi$ is the adjustment coefficient or error correction term. Df and Gov are respectively financial development and governance composite indicator calculated and presented in and table 1 above.

Table 5 presents the results of estimated financial development equation as announced above. It can be seen that the error correction term is negative (-0.432) and significant at the $1 \%$ level, so there is a long-term relationship between the variables in the equation. The results show that in the long run, the effect of governance is positive (0.436) significant at the $1 \%$ level on financial development. Thus, this result reflects the fact that the reforms undertaken in terms of governance performance are notable and contribute to the development of the financial sector. In terms of GDP per capita, the effect of GDP positively and significantly explains financial development at the $1 \%$ level. This means that economic development stimulates the demand for financial services, which is manifested by an increase in savings and credit. An expected result is the significance of the inflation coefficient on financial development, which is positive. These results are not consistent with those found by Keho, (2012), who shows that inflation negatively impacts financial development in his study of six WAEMU member countries. As regards trade openness, is consistent with the results of Keho (2012) and has a positive and significant elasticity on financial development. This result reflects the fact that financial development and trade openness are moving in the same direction and that 
a $1 \%$ increase in openness will lead to a $0.662 \%$ increase in financial development. Thus, the reforms aiming at large opening to outside world will be favourable to the development of the financial sector since they encourage trade and international financial transactions.

Table 6: Estimation of growth equation with $\log Y$ as dependent variable

\begin{tabular}{|c|c|c|c|c|c|}
\hline $\log Y$ & & PMG & & MG & \\
\hline & Variables & Coefficients & Z-stat & Coefficients & Z-stat \\
\hline & $\log \operatorname{Inf}$ & $-0.786^{*}$ & -4.15 & -0.629 & -1.18 \\
\hline & $\log O p$ & $0.174 *$ & 3.20 & 0.222 & 1.42 \\
\hline \multirow[t]{5}{*}{ Long Run } & $\log D f$ & $0.092 * * *$ & 1.84 & 0.072 & 0.20 \\
\hline & Gov & 0.056 & 1.01 & -0.030 & -0.12 \\
\hline & $D f * G o v$ & $0.399 *$ & 4.81 & 0.069 & 0.12 \\
\hline & $\Delta \log I n f$ & 0.083 & 0.47 & 0.162 & 1.27 \\
\hline & $\Delta \log O p$ & -0.019 & 0.395 & -0.027 & -1.26 \\
\hline \multirow[t]{5}{*}{ Short Run } & $\Delta \log D f$ & -0.106 & -0.323 & -0.107 & -0.76 \\
\hline & $\Delta G o v$ & -0.081 & 0.247 & -0.052 & -0.52 \\
\hline & $\Delta D f^{*} G o v$ & 0.196 & 0.83 & 0.111 & 0.37 \\
\hline & Cons & $0.589 *$ & 2.52 & $0.983^{*}$ & 3.47 \\
\hline & $\psi$ & $-0.185^{*}$ & -2.43 & $-0.344^{*}$ & -3.59 \\
\hline
\end{tabular}

Source: Calculations by the author. Notes: $* * *$ and $* * *$ denote respectively the significance of the coefficients of the variables of interest at the 1\%, 5\% and $10 \%$ level. $\psi$ is the adjustment coefficient or error correction term. Df and Gov are respectively a synthetic financial development and governance indicators calculated and presented in table 1 above.

Table 6 presents the results of the estimates of economic growth equation. The PMG estimation results show that, in the long run, with the exception of governance composite indicator, all our variables are significant. Moreover, the level of coefficients, the governance variable is positive but insignificant while inflation exhibit negative sign and significant at the conventional level. The long-run recall force of the estimated error-correction term is negative (-0.185) and significant at $5 \%$. This confirms that there is a long-term relationship between the variables and the presence of any shock is reabsorbed at $18.5 \%$.

A surprising result emerges for inflation and trade openness. Indeed these variables are positive but not significant. The negative sign of inflation coefficient $(-0.786)$ and positive sign of trade openness $(0.174)$ respectively significant imply that policy of evaluating economic growth in general in WAEMU area take into account inflation and trade openness. Moreover, these signs are in line with the literature, which means that taking inflation and trade openness into account will be favourable to economic development. Financial development has a positive and 
significant effect, which means that economic development and economic growth are moving in the same direction. A $1 \%$ increase in financial development leads to $0.092 \%$ economic growth. Although they move together, the elasticity of financial development $(0.092 \%)$ is less than 1 , so economic growth as measured here by GDP per capita is inelastic with respect to long-term financial development. Growth is very insensitive to changes in financial development. The direct effect of governance quality on economic growth is positive and insignificant at the conventional level. This result is justified by the fact that the average of governance composite indicator selected for all the Union are comprise between -1 and 1 . Therefore, an improvement in quality of governance will be favourable to growth due to the positive of governance coefficient (0.056). This result is contrary to those of Abdelkarim et al., (2009) and Kuipou et al (2015), who found a positive and significant relationship between governance and economic growth in the WAEMU area.

Taking into account the interaction variable between financial development and governance, the interaction is found to have positive and statistically significant effect on economic growth. This result is lined with that of Keho, (2012) and Abdelkarim et al., (2009). This can be explained by the fact that an improvement in governance (political stability, rule of low, corruption and democracy) will drive up economic growth. Taking into account the quality of governance in the relationship between financial development and economic growth is a fundamental fact in explaining the effect of financial development on growth in the WAEMU area. To understand the importance of governance in finance-growth relationship, we assess the marginal effect of financial development for a given level of governance quality. For example, considering a quality of governance equal to the average in the sample, an increase in level of financial development by one standard deviation point leads to an increase of $\beta_{3} \times \sigma_{D f}+\beta_{5} \times \overline{D f} \times \sigma_{D f}=0.69 \%$ for real activity. This outcome means that financial development affects positively growth and the quality of governance sustains that positive effect. Tables 7, 8 and 9 in the appendix present the results of the estimates of the financial development equation (by disaggregating the financial development variable used, namely credit granted to the private sector, domestic credit granted by the banking sector and mass monetary as defined in Table 1. Upon examination of our results, we found that the effect of governance factors varies in long term depending on the financial development variable considered. Indeed, the coefficients of governance quality indicators have a significant effect (even the obtained coefficients have difference signs) on financial development regardless the variable retained with the exception of corruption as well as the variable rule of low when the domestic credit granted by the banking sector as financial development variable is taken into account. This result is consistent with those of Gries et al. (2009), Keho (2012). It should be noted that the coefficient of elasticity of governance variable measuring the size of the rule of law variable has a negative and significant impact when the financial development variable credit granted to private sector and money supply are considered. Thus, 
these results reflect the efforts undertaken in terms of strengthening rule of law in Union are not significant and have not resulted in financial deepening. Also its efforts do not contribute to financial sector development.

Furthermore, with regard to the control variables, we note that the four (4) financial development variables retained, for each of them, the elasticity coefficient of inflation variable is positive and significant. This result is contrary to literature on financial repression. This positive coefficient does not necessarily mean that inflation positively influences financial development either. But on the contrary, it would indicate that the measures implemented to contain inflation in the WAEMU zone have contributed to the improvement of financial deepening in these countries. This result is consistent with those of Kos et al (2016). The variable "trade openness" also has a positive and significant impact on the financial development indicators used in PMG except in the case of the financial development variable such as money supply and the governance variable like rule of law where the coefficient is negative and significant in MG. This robust (positive) result of the effect of trade openness in PMG is in line with the work of Baltagi et al., (2009), Seetanah et al., (2010) and Keho (2012) would indicate that reforms aimed at greater openness are favorable to the development of the financial sector since they encourage trade and international financial transactions.

As for the GDP per capita, when the financial development variables are considered, it presents a positive and significant elasticity in all our regressions except in the presence of the governance variable (democracy). This positive sign shows that economic development is stimulating demand for financial services, which in turn translates into increased savings and credit. Table 10 summarizes the results of longterm estimates of the growth equation for each of the governance variables. We note that the direct effect of composite financial development and governance indicator on economic growth is positive and respectively significant and not significant. These results join those obtained by Bertelemy and Varoudakis (1998) and Kuipou et al. (2012). The positive effect of governance composite indicator variable in the UEMOA zone, demonstrates that governance looks good because the average of all governance indicators is between 0 and -1 . This is why they make a favorable contribution to economic development. This result is close to those obtained by Kuipou et al. (2015) who found that the UEMOA zone governance index has a positive and significant effect. The positive effect of composite financial development indicator in Union shows that financial development influences economic development and a 10\% increase in financial development will lead to an increase in economic development about $0.919 \%$. By taking into account the interaction variable between financial development and governance, we find that the interaction has a positive and statistically significant effect on economic growth. This result is consistent with that of Keho (2012) and Abdelkarim et al. (2009). This can be explained by the fact that in the UEMOA zone, despite the "poor quality" of governance, the financial system is more dominated by financial markets to the detriment of bank loans. So an improvement in governance (political stability, rule of law, corruption and democracy) will be favorable to economic growth. As for the 
macroeconomic variables, the inflation variable presents globally negative and significant effects while the trade openness variable has a positive and significant coefficient. This means that trade openness contributes to economic development.

\section{Conclusion and Policy recommandations}

This work examines the relationship between governance, financial development and economic growth. Our analysis focused on panel data from seven countries in the WAEMU area over the period 1996-2018. We first analyzed the effect of governance consisting corruption, rule of law, democracy, and political instability on financial development and then studied the impact of the direct effect of governance, financial development and their interaction on economic growth. This is done through the methodology based on the PMG estimator which allows us to estimate the long and short term relationship for each country in the area with ARDL model in line of the existing literature, the results of our empirical study show that there is long run relationship between governance and financial development and then between financial development, governance and economic growth in the WAEMU area. A good quality of governance induces a development of the financial system. Thus, good governance is presented as a determinant of financial development. We have also shown that good governance provides favourable environment for financial development and consequently for economic growth. We note that the direct effect of composite financial development and governance indicators on economic growth is positive and respectively significant and not significant. These results join those obtained by Bertelemy and Varoudakis (1998) and Kuipou et al., (2012). The positive effect of governance composite indicator variable in the UEMOA zone demonstrates that governance looks good because the average of all governance indicators is between 0 and -1 . This is why they make a favorable contribution to economic development. This result is close to those obtained by Kuipou et al. (2015) who found that the UEMOA zone governance index has a positive and significant effect. By taking into account the interaction variable between financial development and governance, we find that the interaction has a positive and statistically significant effect on economic growth. This result is consistent with that of Keho (2012) and Abdelkarim et al. (2009). This can be explained by the fact that in the UEMOA zone, despite the "poor quality" of governance, the financial system is more dominated by financial markets to the detriment of bank loans. So an improvement in governance (political stability, rule of law, corruption and democracy) will be favorable to economic growth. Furthermore, the policy makers should improve the quality of governance or institution quality such as political stability, corruption, rule of law and democracy. Indeed, we suggest strengthening more democracy and rule of law, this could offer more guarantees to banks for granting long-term credits. These various measures thus constitute the challenges that the countries of WAEMU area will have to face in order to contribute to the development of financial system and economic development. 


\section{References}

[1] Abdelkarim, Y. and Atef R. (2009). Développement financier et croissance économique: Rôle de la qualité des institutions. . Panoeconomicus, 3: 327-357.

[2] Acemoglu, D., Johnson, S., and Robinson, J. (2004). Institutions as the Fundamental Cause of Long-Run Growth. National Bureau of Economic Research, Working Paper 10481.

[3] Arellano, M., and Bond, S. (1991). Some tests of specification for panel data: Monte carlo evidence and an application to employment equations. Review of Economic Studies, 58(2):277-97.

[4] Arellano, M., and Bover O. (1995). "Another look at the instrumental variable estimation of error-components models". Journal of Econometrics, 68, pp. 2952.

[5] Arestis, P., Demetriades, P., Fattouh B., and Mouratidi, K. (2002). "The Impact of Financial Liberalization Policies on Financial Development : Evidence from Developing Economies". International Journal of Finance \& Economics , 7(2), 109-121.

[6] Atindéhou, R. B., Gueyie, J. P., and Amenounve, E. K. (2005). Financial Intermediation and Economic Growth: Evidence from Western Africa". Applied Financial Economics 15, 777-790.

[7] Baltagi, B.H., Demetriades P. O., and Law, S. H. (2009). "Financial Development and Openness :Evidence from Panel Data". Journal of Development Economics , 89, 285-296.

[8] Bandiera, O., Capio, G., Honohan, P., and Schiantarelli, F. (2000). "Does Financial Reform Raise or Reduce Savings ? "Review of Economics and Statistics., 82(2), 239-263.

[9] Benhabib, J., Spiegel, M. M. (2000). "The Role of Financial Development in Growth and Investment". Journal of Economic Growth, 5, 341-360.

[10] Berthélbemy, J.C. and Varoudakis, A. (1998). "Clubs de Convergence et Croissance. Le Rôle du Développement financier et du Capital Humain". Revue économique, 46(2), 217-235.

[11] Boyd, J. H., Levine, R., and Smith, B. D. (2001). "The Impact of Inflation on Financial Sector Performance" . Journal of Monetary Economics , 47, 221248.

[12] Burcu, K., Nilgün, Ç., and Burak, G. (2009). "Financial Development and Economic Growth: A Panel Data Analysis of Emerging Countries". International Research Journal of Finance and economics, 30, 87-94.

[13] Calderon, C. and Liu, L. (2003). "The Direction of Causality between Financial Development and Economic Growth". Journal of Development Economics , 72, 321-334.

[14] Cho, Y. J. (1986). Inefficiencies from Financial Liberalization in the absence of well Functioning Equity Markets. Journal of Money, Credit and Banking, 18(2), 191-199. 
[15] Chouchane-Verdier, A. (2004). "Une analyse empirique de l'impact de la libéralisation financière en Afrique subsaharienne sur la période 1983-1996. Tiers-Monde, 45(179), 617-641.

[16] De Gregorio, J. and Guidotti, P. (1995). "Financial Development and Economic Growth". World Development, 23(3), 433-448.

[17] De Gregorio, J. and Guidotti, P. (1995). "Financial Development and Economic Growth", . World development, 23(3), 433-448.

[18] Deidda, L. and Fattouh, B. (2002). "Nonlinearity between Finance and Growth". Economic Letters, 74, 339-345.

[19] Diery, S. and Yasim, E. H. (1993). "Financial Liberalization in Africa". World Development, 21(11),1867-1881.

[20] Ebert, U. and Welsch, H. (2004). Meaningful environmental indices: a social choice approach. Journal of Environmental Economics and Management, Vol. 47: 270-283.

[21] Eboué, C. (1990). Les Effets macroéconomiques de la répression financière dans les pays en développement. Economie Appliquée, Tome LXIII, No.4, 93-117.

[22] Giovannini, A. and de Melo, M. (1993). "Government Revenue from Financial Repression". The American Economic Review., 83(4), 953-963.

[23] Greenwald, B. and Stiglitz, J. E. and Weiss, A. (1994). Informational Imperfections in the Capital Market and Macroeconomic Fluctuations". American Economic Review, 74(2), 194-200.

[24] GREGORY MANKIW, DAVID ROMER, \& DAVID N. WEIL . (1992). A CONTRIBUTION TO THE EMPIRICS OF ECONOMIC GROWTH. Quaterly Journal of Economics, P. 407-437.

[25] Gries, T. and Redlin, M. (2009). Trade openness and economic growth: A panel causality analysis. Centre for International Economics, Canberra, Australia Working paper series, no. 2011-06.

[26] Gurley, J. G. and Shaw, E. S. (1955). "Financial Aspects of Economic Development". American Economic Review, 45(4), 515-538.

[27] Hsiao, C., Pesaran, M. H. and Tahmiscioglu, A. K. (1999). Bayes Estimates of Short run Coefficients in Dynamic Panel Data Models. Cambridge University Press, chapter 11, 268-296.

[28] Huybens, E. and Smith, B. (1999). "Inflation, Financial Markets, and Long Run Real Activity". Journal of Monetary Economics, Vol. 43, 283-315.

[29] Joseph, A., Raffinot, M. and Vénet, B. (1998). "Approfondissement Financier et Croissance :Analyses Empiriques en Afrique Sub-saharienne". Techniques Financières et Développement, 52, 17-25.

[30] Kao. C. (1999). Spurious regression and residual-based tests for cointegration in panel data. Journal of Econometrics, 90, pp. 1-44.

[31] Kaufmann, D., Kraay, A. and Mastruzzi, M. (2010). "The Worldwide Governance Indicators, Methodology and Analytical issues". World Bank Working, Paper $\mathrm{n}^{\circ} 5430$. 
[32] Keho, Y. (2012). Le rôle des facteurs institutionnels dans le développement financier et Economique des pays de l'WAEMU. Revue économique et monétaire, (12): 9-43.

[33] King, R. and Levine, R. (1993). "Finance, Entrepreneurship, and Growth : Theory and Evidence". Journal of Monetary Economics, 32(3), 513-542.

[34] Kiviet, J. F. (1995). "On Bias, Inconsistency and Efficiency of Various Estimators in Dynamic Panel Models". Journal of Econometrics, 68, 53-87.

[35] Knack, S. and Keefer, P. (1995). "Institutions and Economic Performance : Cross-country Tests using Alternative Institutional Measures". Economics and Politics, 7 (3), 207-227.

[36] Kuipou, T. C., Nembot, N. L. and Tafah Edokat, O. E. (2015). Développement financier et croissance économique dans les pays africains de la area franc : le rôle de la gouvernance. European Scientific Journal , 131-159.

[37] Kuipou. T. C., Nembot N. L. and Tafah O. E. (2012). «Financial Development and Economic Growth in CEMAC Countries ». Global Journal of Management and Business Research, volume XII version 1.

[38] Levine, R. and Renelt, D. (1992). "A Sensitivity Analysis of Cross Country Growth Regressions". American Economic Review, 82(4), 942-963.

[39] Levine, R. and Zervos, S. (1998). "Stock Markets, Banks and Economic Growth". American Economic Review, 88, 537-558.

[40] Levine, R., Loayza, N. and Beck, T. (2000). "Financial Intermediation and Growth: Causality and Causes. Journal of Monetary Economics, 46(1), 31-77.

[41] Mahar, J. and Williamson, M. (1998). "A Survey of Financial Liberalization". Essays in International Finance, Department of Economics, Princeton University, No. 211.

[42] Mckinnon, R.I. (1973). Money and capital in Economic Development. the Brooking Institution, Washington.

[43] Moez, O. (2011). Etude empirique de la Relation entre le Système Monetaire et Financier et la Croissance Economique. Soutenue le 21.04.2011.

[44] Nelson, R. R. and Sampat, B. N. (2001). "Making Sense of Institutions as a Factor Shaping Economic Performance". Journal of Economic Behavior \& Organization, 44(1), 31-54.

[45] North, D. C. (1990). Institutions, Institutional Change, and Economic Performan. Cambridge University Press.

[46] Odedokun, M. O. (1996). "Alternative Econometric Approaches for Analyzing the Role of the Financial Sector in Economic Growth: Time-Series Evidence from LDCs". Journal of, Development Economics, 50(1), 119-135.

[47] Pedroni, P. (1999). Critical values for cointegration tests in heterogenous panels with multiple regressors. Oxford Bulletin of Economics and Statistics, S1, 61, pp. 653-670., S1, 61, pp. 653-670.

[48] Pesaran, H. S. (1999). "An Autoregressive Distributed Lag Modelling Approach to Cointegration". Econometrics and Economic Theory in the 20th Century :Chapter 11, Cambridge University Press. 
[49] Pesaran, M. H. and Smith, R. P. (1995). "Estimating Long-run Relationship from Dynamic Heterogeneous Panel". Journal of Econometrics., 68(1), 79113.

[50] Pesaran, M. H., Shin Y. and Smith R. P. (1999,2000). "Pooled Mean Group Estimation of Dynamic Heterogeneous Panels". Journal of American Statistical Association , 94(446), 621-634.

[51] Rajan, R. and Zingales, L. (2003). "The Greats Reversals: The Politics of Financial Development in the Twentieth Century". Journal of Financial Economics, 69(1), 5-50.

[52] Ram, R. (1999). "Financial Development and Economic Growth: Additional Evidence". Journal of Development Studies, 35, 164-174.

[53] Reinhart, C. and Tokatlidis, I. (2003). Financial Liberalization: The African Experience" Journal of African Economies, 12(2), 53-88.

[54] Rioja, F. and Valev, N. (2004). "Finance and the Sources of Growth at Various Stages of Economic Development". Economic Inquiry , 42, 127-140.

[55] Robert, M. S. (1956). "A Contribution to the Theory of Economic Growth,". The Quarterly Journal of Economics, Oxford University Press, vol. 70(1), pages 65-94.

[56] Robinson, J. (1952). The Rate of Interests and Other Essays. Macmillan, London.

[57] Rodrik, D. S. (2003). "La Primauté des institutions". Finance et Developpement, Juin, pp.31-34.

[58] Rousseau, P.L. and Wachtel, P. (2002). "Inflation Thresholds and the FinanceGrowth Nexus". Journal of International Money and Finance, 21, 777-793.

[59] Schumpeter, J. (1912). The Theory of Economic Development. MA : Harvard. [60] Seetanah, B., Padachi, K. and Hosany, J. (2010). Determinants of financial development: The case of Mauritius. IN Finance and Corporate Governance Conference.

[61] Shaw, E. S. (1973). Financial Deepening in Economic Growth. Oxford Univ. Press, NY.

[62] Stiglitz, J. and Weiss, A. (1981). Credit Rationing in Markets with Imperfect Information. American Economic Review, 71(3), 393-410.

[63] Van Wijnbergen, S. (1983). "Interest Rate Management in LCD's". Journal of Moneta Economics, 12(3), 433-452.

[64] Wurgler, J. (2000). "Financial Markets and the Allocation of Capital". Journal of Financial Economics, 58(1-2), 187-214.

[65] Zhang, K. (2003). "Does Financial Development Promote Economic Growth in the East Asia ?". China Journal of Finance , 1, 1-10. 
Appendix: Additional Tables

Table 7: Estimation of Financial development equation with Credit granted to the private sector as dependent variable ( $\log D f=$ Credit granted to the private sector)

\begin{tabular}{|c|c|c|c|c|c|c|c|c|c|}
\hline \multirow{2}{*}{\multicolumn{2}{|c|}{$\begin{array}{c}\log D f \\
\text { Variables }\end{array}$}} & \multicolumn{8}{|c|}{ GOVERNANCE INDICATORS } \\
\hline & & \multicolumn{2}{|c|}{ Political Stability } & \multicolumn{2}{|c|}{ Corruption } & \multicolumn{2}{|c|}{ Rule of low } & \multicolumn{2}{|c|}{ Democraty } \\
\hline \multirow{5}{*}{$\begin{array}{l}\text { Long } \\
\text { run }\end{array}$} & & PMG & MG & PMG & MG & PMG & MG & PMG & MG \\
\hline & $\log \operatorname{Inf}$ & $60,68 *$ & $69,83^{*}$ & $57,05^{*}$ & $117,04 *$ & $45,08^{*}$ & $66,99 *$ & $31,03 *$ & 50,17 \\
\hline & $\log O p$ & $16,51^{*}$ & 4,36 & $10,38^{*}$ & 1,81 & $14,5^{*}$ & 5,14 & $14,54^{*}$ & 7,17 \\
\hline & Gov & $3,62 *$ & $-2,3$ & $-3,52$ & 4,72 & $-1,99$ & $-4,97$ & $1,72 * *$ & $-1,87$ \\
\hline & $\log G D P$ & $60,63^{*}$ & 36,04 & $31,13^{* *}$ & $-0,05$ & $40,79 *$ & 33,71 & $59,69^{*}$ & $56,77 * *$ \\
\hline \multirow{7}{*}{$\begin{array}{c}\text { Short } \\
\text { run }\end{array}$} & $\log \operatorname{Inf}$ & $-25,45^{*}$ & $-26,12 *$ & $-31,69 *$ & $-36,57 *$ & $-32,14^{*}$ & $-28,15$ & $-19,96 * *$ & $-11,18$ \\
\hline & $\log O p$ & $-7,17^{*}$ & $-4,33$ & $-5,39$ & $-4,82$ & $-5,66^{* *}$ & $-2,48$ & $-6,00 * *$ & $-4,48$ \\
\hline & Gov & $-0,47$ & 0,63 & $2,89 *$ & 1,52 & $-0,18$ & 0,61 & $2,62 * *$ & 4,12 \\
\hline & $\log G D P$ & $-46,14 *$ & $-39,45^{*}$ & $-27,98$ & $-29,81 *$ & $-21,55$ & $-28,56^{*}$ & $-38,35$ & $-51,31 *$ \\
\hline & Cons & $-94,55^{*}$ & $-155,77 *$ & $-56,84 *$ & $-118,97 *$ & $-61,25^{*}$ & $-128,84 *$ & $-73,52 *$ & $-158,97^{*}$ \\
\hline & $\psi$ & $-0,35^{*}$ & $-0,67 *$ & $-0,3^{*}$ & $-0,57 *$ & $-0,32 *$ & $-0,58 *$ & $-0,34 *$ & $-0,61 *$ \\
\hline & Hausman & \multicolumn{2}{|c|}{0,2672} & \multicolumn{2}{|c|}{$\mathbf{0 , 3 0 6 1}$} & \multicolumn{2}{|c|}{0,0911} & \multicolumn{2}{|c|}{$\mathbf{0 , 2 5 1 2}$} \\
\hline & $\begin{array}{c}\text { Log } \\
\text { Likelihood }\end{array}$ & \multicolumn{2}{|c|}{$-248,8507$} & \multicolumn{2}{|c|}{$-251,7527$} & \multicolumn{2}{|c|}{$-251,2726$} & \multicolumn{2}{|c|}{$-249,6671$} \\
\hline
\end{tabular}

Source: Calculations by the author. Notes: *** and *** denote respectively the significance of the coefficients of the variables of interest at the $1 \%, 5 \%$ and $10 \%$ level. $\psi$ is the adjustment coefficient or error correction term. 
Table 8: Estimation of Financial development equation with domestic credit granted by the banking sector as dependent variable $(\log D f=$ domestic credit granted by the banking sector)

\begin{tabular}{|c|c|c|c|c|c|c|c|c|c|}
\hline \multirow{2}{*}{\multicolumn{2}{|c|}{$\begin{array}{c}\log D f \\
\text { Variables }\end{array}$}} & \multicolumn{8}{|c|}{ GOVERNANCE INDICATORS } \\
\hline & & \multicolumn{2}{|c|}{ Political Stability } & \multicolumn{2}{|c|}{ Corruption } & \multicolumn{2}{|c|}{ Rule of low } & \multicolumn{2}{|c|}{ Democraty } \\
\hline \multirow{5}{*}{$\begin{array}{l}\text { Long } \\
\text { run }\end{array}$} & & PMG & MG & PMG & MG & PMG & MG & PMG & MG \\
\hline & $\log \operatorname{Inf}$ & $59,75^{*}$ & $69,79 *$ & $56,81^{*}$ & $115,99 *$ & $44,17 *$ & $66,46^{*}$ & $26,57 *$ & 50,09 \\
\hline & $\log O p$ & $16,65^{*}$ & 4,09 & $10,00^{*}$ & 1,77 & $14,41 *$ & 4,96 & $13,79^{*}$ & 6,96 \\
\hline & Gov & $3,71 *$ & $-2,19$ & $-3,57$ & 4,59 & $-1,89$ & $-4,99$ & $2,03^{*}$ & $-1,85$ \\
\hline & $\log G D P$ & $62,43 *$ & 37,2 & $31,18^{* *}$ & 1,37 & $42,03 *$ & 34,85 & $70,15^{*}$ & $57,42 * *$ \\
\hline \multirow{8}{*}{$\begin{array}{l}\text { Short } \\
\text { run }\end{array}$} & $\log \operatorname{Inf}$ & $-23,98 *$ & $-25,13 * *$ & $-30,72 *$ & $-35,42 *$ & $-30,61^{*}$ & $-26,74 *$ & $-16,25$ & $-10,19$ \\
\hline & $\log O p$ & $-7,09 * *$ & $-3,98$ & $-5,32$ & $-4,74$ & $-5,66^{* *}$ & $-2,39$ & $-5,56^{* *}$ & $-4,3$ \\
\hline & Gov & $-0,45$ & 0,62 & $3,01 *$ & 1,66 & $-0,12$ & 0,71 & $2,86^{* *}$ & 4,21 \\
\hline & $\log G D P$ & $-46,03 *$ & $-39,97 * *$ & $-27,12$ & $-29,76^{*}$ & $-21,54$ & $-29,09^{*}$ & $-41,18 * *$ & $-51,48^{*}$ \\
\hline & Cons & $-93,83^{*}$ & $-160,2^{*}$ & $-56,21 *$ & $-121,85^{*}$ & $-61,18^{*}$ & $-131,28 *$ & $-83,02 *$ & $-161,63^{*}$ \\
\hline & $\psi$ & $-0,34 *$ & $-0,67 *$ & $-0,3^{*}$ & $-0,58 *$ & $-0,32 *$ & $-0,58 *$ & $-0,35^{*}$ & $-0,62 *$ \\
\hline & Hausman & \multicolumn{2}{|c|}{0,2688} & \multicolumn{2}{|c|}{0,2997} & \multicolumn{2}{|c|}{0,0683} & \multicolumn{2}{|c|}{0,1555} \\
\hline & $\begin{array}{c}\text { Log } \\
\text { Likelihood }\end{array}$ & \multicolumn{2}{|c|}{$-249,1912$} & \multicolumn{2}{|c|}{$-251,8019$} & \multicolumn{2}{|c|}{$-251,5803$} & \multicolumn{2}{|c|}{$-249,5908$} \\
\hline
\end{tabular}

Source: Calculations by the author. Notes: *,** and $* * *$ denote respectively the significance of the coefficients of the variables of interest at the 1\%,5\% and $10 \%$ level. $\psi$ is the adjustment coefficient or error correction term. 
Table 9: Estimation of Financial development equation with money supply ratio as dependent variable $(\log D f=$ money supply ratio)

\begin{tabular}{|c|c|c|c|c|c|c|c|c|c|}
\hline \multirow{3}{*}{\multicolumn{2}{|c|}{$\begin{array}{c}\log D f \\
\text { Variables }\end{array}$}} & \multicolumn{8}{|c|}{ GOVERNANCE INDICATORS } \\
\hline & & \multicolumn{2}{|c|}{ Political Stability } & \multicolumn{2}{|c|}{ Corruption } & \multicolumn{2}{|c|}{ Rule of low } & \multicolumn{2}{|c|}{ Democraty } \\
\hline & & PMG & MG & PMG & MG & PMG & MG & PMG & MG \\
\hline \multirow{4}{*}{$\begin{array}{l}\text { Long } \\
\text { run }\end{array}$} & $\log \operatorname{Inf}$ & $96,67 *$ & $221,11 *$ & $56,90 *$ & $141,62 *$ & $63,29 *$ & $184,95^{*}$ & $52,97 *$ & $162,11 *$ \\
\hline & $\log O p$ & $16,33 *$ & $-12,72$ & $20,36^{*}$ & 1,05 & $20,35^{*}$ & $-3,49$ & $18,61 *$ & $-6,53$ \\
\hline & Gov & $4,71 *$ & $-3,92$ & $6,23 * *$ & 11,62 & $8,66^{*}$ & $-4,06$ & $15,95 *$ & $19,3^{*}$ \\
\hline & $\log G D P$ & $54,94 *$ & $-34,4$ & $73,49 *$ & $-10,35$ & $56,77 *$ & $-22,82$ & 21,86 & $-28,24$ \\
\hline \multirow{8}{*}{$\begin{array}{c}\text { Short } \\
\text { run }\end{array}$} & $\log \operatorname{Inf}$ & $-57,57^{*}$ & $-76,14^{*}$ & $-50,78 *$ & $-73,2 *$ & $-61,15^{*}$ & $-77,56^{*}$ & $-59,73 *$ & $-70,58^{*}$ \\
\hline & $\log O p$ & $-4,37 * *$ & 0,98 & $-5,36^{*}$ & $-3,91$ & $-5,07 * *$ & $-0,11$ & $-4,29$ & $-2,34$ \\
\hline & Gov & 0,16 & 1,88 & 1,38 & 0,14 & 2,2 & 4,15 & 2,26 & $-0,33$ \\
\hline & $\log G D P$ & $-8,59$ & $-8,27$ & $-12,2$ & $-14,34$ & $-10,59$ & $-1,87$ & $-18,88$ & $-11,04$ \\
\hline & Cons & $-94,73^{*}$ & $-125,88^{*}$ & $-81,11^{*}$ & $-164,19 * *$ & $-78,26^{*}$ & $-119,22 *$ & $-44,47 *$ & $-64,01^{*}$ \\
\hline & $\psi$ & $-0,29 *$ & $-0,49 *$ & $-0,27 *$ & $-0,54 *$ & $-0,29 *$ & $-0,43^{*}$ & $-0,31^{*}$ & $-0,48^{*}$ \\
\hline & Hausman & \multicolumn{2}{|c|}{0,2525} & \multicolumn{2}{|c|}{0,0011} & \multicolumn{2}{|c|}{0,1863} & \multicolumn{2}{|c|}{0,1053} \\
\hline & $\begin{array}{c}\text { Log } \\
\text { Likelihood }\end{array}$ & \multicolumn{2}{|c|}{$-303,5645$} & \multicolumn{2}{|c|}{$-303,8533$} & \multicolumn{2}{|c|}{$-301,3668$} & \multicolumn{2}{|c|}{$-290,2647$} \\
\hline
\end{tabular}

Source: Calculations by the author. Notes: $* * *$ and $* * *$ denote respectively the significance of the coefficients of the variables of interest at the 1\%, 5\% and $10 \%$ level. $\psi$ is the adjustment coefficient or error correction term.

Table 10: Estimation of growth equation with $\log G D P$ as dependent variable.

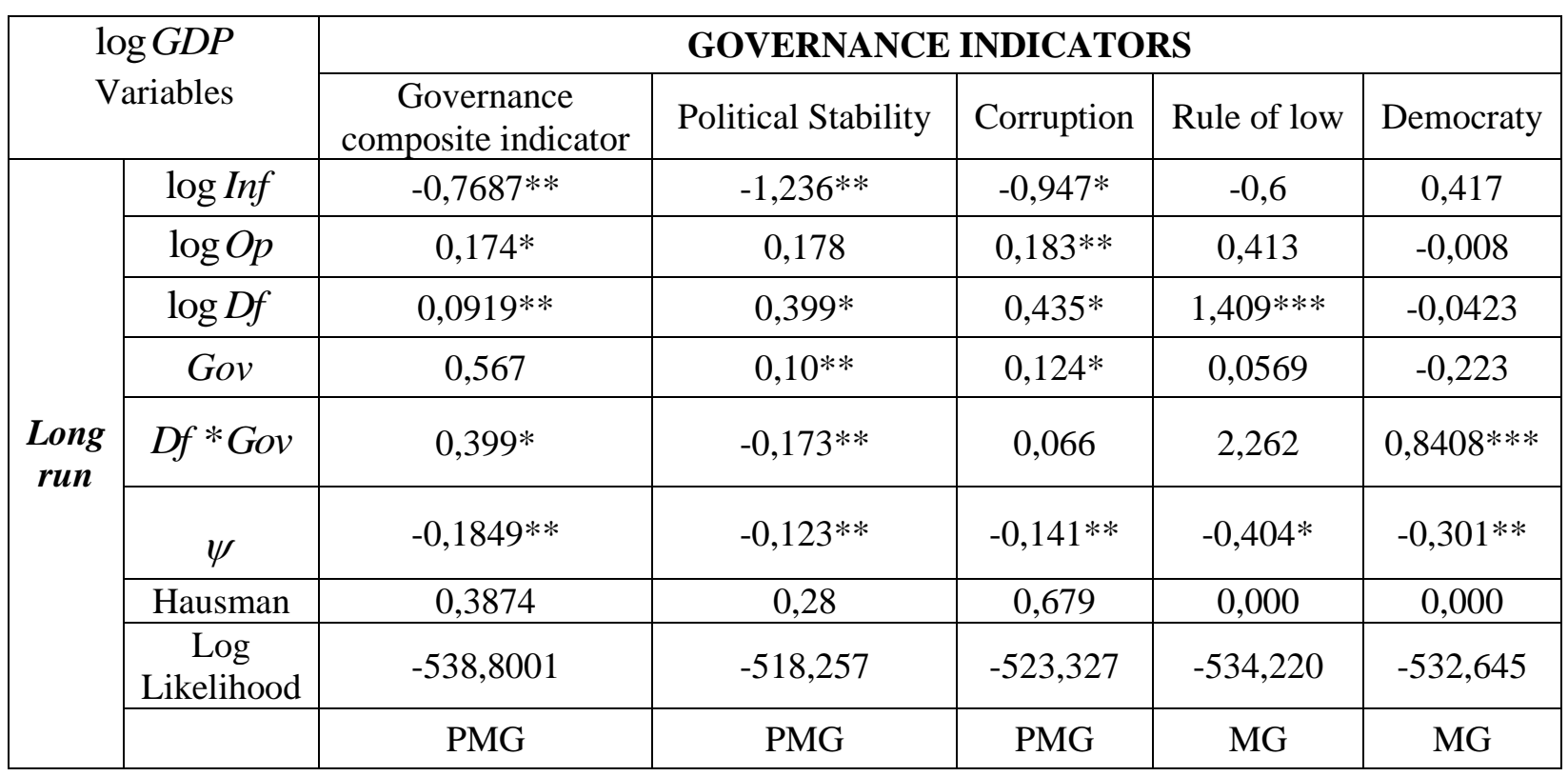

Source: Calculations by the author. Notes: $* * *$ and $* * *$ denote respectively the significance of the coefficients of the variables of interest at the $1 \%, 5 \%$ and $10 \%$ level. $\psi$ is the adjustment coefficient or error correction term. 